УДК $504.03(477.41 / 42)$

DOI: $10.15587 / 2313-8416.2015 .51471$

\title{
CARCINOGENIC AND NON-CARCINOGENIC RISK FROM CONSUMING OF EDIBLE MACROMYCETES GROWING IN AN ECOLOGICAL CONDITIONS OF OLEVSK DISTRICT
}

\author{
(C) T. Myslyva, Yu. Bilyavskyj, P. Nadtochij
}

It was ascertained that the mycological products growing within the natural ecosystem zones in Zhytomyr Region, in particular the Olevsk district thereof, are considered to be ecologically hazardous, and its consumption by people might result in escalation of both carcinogenic and not carcinogenic health hazards

Keywords: heavy metals, macromycetes, environmental safety, carcinogenic risk, non-carcinogenic risk

\begin{abstract}
Встановлено, щзо мікологічна продукиія, яка зростає на території природних екосистем Олевського району Житомирської області, є екологічно небезпечною, а їі споживання населенням призводить до збільшення не канцерогенного і канцерогенного ризику для здоров'я

Ключові слова: важкі метали, макромічети, екологічна безпечність, канцерогенний ризик, не канцерогенний ризик
\end{abstract}

\section{Introduction}

Such foodstuffs as fungi are considered to be the traditional food for inhabitants of the forest areas of the state, in particular the Olevsk district of Zhytomyr Region. Prevalence of various species of the edible fungi in the forests of Zhytomyr Polissia, high yield and traditional consumption thereof by local inhabitants provide for delivery of microelements, inclusive of pollutants, to the organism of a man [1]. Because of unfavourable ecological conditions, the wild fungal cultures may be significantly contaminated and therefore not safe for people as the mycobiota is known for its high pollutant accumulation ability [2-7]. Therefore, environmental researches of the specific accumulation of various chemicals, in particular heavy metals, by the edible macromycetes as well as the estimation of risk from its consuming have become very actual and reasonable to the date.

2. Review of recent researches and publications and a problem statement

Regular long-term researches in the field of accumulation of heavy metals by fungi and potential hazard induced by consumption of the mycological products by people have not been effectively described in modern domestic science-oriented literature, except for certain researches performed under local conditions of Rivne [8] and Transcarpathian [9] Regions. The closer attention is paid by modern researchers to the specific accumulation and behaviour of the radioactive elements containing in the mycological products. Results of such researches are published in works of O. Orlov and others [10-12]. Selection of the declared research is conditioned by the fact that neither research involving assessment of carcinogenic and not carcinogenic hazard of fungi consumption by people living within the residential areas, in particular the Olevsk District of Zhytomyr Region has been previously performed.

\section{Purpose and tasks of research}

The purpose of research assumes assessment of specific accumulation of $\mathrm{Cu}, \mathrm{Pb}, \mathrm{Cd}, \mathrm{Zn}$ and $\mathrm{Mn}$ by various species of the wild edible macromycetes with either tubular or lamellar hymenophore growing within the forest ecosystem zones in Zhytomyr Region, in particular the Olevsk District thereof. Also it involves determination of both carcinogenic and not carcinogenic health hazards for rural residents consuming polluted fungi. The objectives of research are as follows:

1) determination of contamination level for the topsoil, forest floor and leaf litter located within the area of natural woodland ecosystems;

2) estimation of contamination level and identification of the specific accumulation of heavy metals in mycothalluses of the edible fungi with either tubular or lamellar hymenophore growing within the areas of natural woodland ecosystems;

3 ) determination of scale of carcinogenic and not carcinogenic health hazard for people affected by chemicals penetrating into organism through consumption of polluted macromycetes.

4. Materials and methods of research of carcinogenic and non-carcinogenic risk from the consuming of edible mushrooms

\section{1. Research materials}

The said researches were performed in 2012-2014 within the woodland areas near-by villages Budky, Sosnivka, Bilokorovychi and Dibrova Olevsk districts of Zhytomyr Region. The samples of soil, forest floor and fungal mycothalluses were taken in July and August. The aforesaid samples were taken according to requirements of DSTU (Ukrainian State Standard) ISO 10381-4:2005. (ISO 10381-4:2003, IDT). Sampling depth for soil was $0 \ldots .20 \mathrm{~cm}$, while for forest floor $-0 . .5 \mathrm{~cm}$.

\section{2. Research methods}

Carcinogenic and non-carcinogenic health hazard rate was assessed on the basis of the ordinary methodology [13]. Availability of $\mathrm{Cd}, \mathrm{Cu}, \mathrm{Pb}, \mathrm{Mn}$ and $\mathrm{Zn}$ mobile forms in ammonium acetate extraction buffer $(\mathrm{pH} 4.8)$ was determined with help of atomic absorption spectrometry. The mycological cultures were taken from the same places as samples of the soil and forest floor. Each sample included at least three mycothalluses. $\mathrm{Cd}, \mathrm{Cu}, \mathrm{Pb}$, 
$\mathrm{Mn}$ and $\mathrm{Zn}$ content in fungal mycothalluses was determined by atomic absorption spectrophotometry applied upon dry mineralization. The total of three species of the edible fungi with tubular and three species of lamellar hymenophore accordingly has been examined. In order to assess a rate of hazard connected with the pollutant in valid manner, the toxic properties of soil were determined as the zinc equivalent. The test data were statistically processed with help of application software package, inclusive of Microsoft Excel and Statistica 10.0.

5. Results of research of carcinogenic and noncarcinogenic risk from the consuming of edible mushrooms

It is ascertained in the course of research that content of either whole or mobile forms of copper, zinc, lead and cadmium in soils within natural woodland ecosystems does not generally exceed maximum permissible limits as per applicable regulations, except for the con- tent of Cd mobile forms, the concentration of which in the topsoil within the area of certain woodlands has been 1.2-1.7 times more than MAC. Upon calculation of the zinc equivalent of toxic properties it has been ascertained that the topsoil contamination (in terms of the zinc equivalent) is of less- to medium-polluted character, while the forest floor contamination has predominantly medium-polluted level (Table 1). Content of heavy metals in the leaf and coniferous litter, which is a base for substrate, wherein the edible macromycetes grow, generally has average values specified in professional bibliographic sources [2] and is differentiated depending on woody plant species - edificators of the plant groups in the woodland ecosystems.

Upon the results of performed researches there have been determined intensity-based sequences of copper, zinc, lead, manganese and cadmium accumulation in mycothalluses of the edible fungi with either lamellar or tubular hymenophore (Table 2).

Table 1

Level of pollutants (heavy metals) content in soil (layer depth $0 \ldots 20 \mathrm{~cm}$ ) and forest floor (layer depth $0 \ldots 5 \mathrm{~cm}$ ) within woodland ecosystems of Olevsk district in terms of the zinc equivalent of toxic properties

\begin{tabular}{|c|c|c|c|c|}
\hline \multirow{2}{*}{ Place of researches } & \multirow{2}{*}{ Soil type } & \multirow{2}{*}{$\begin{array}{l}\text { Description of the } \\
\text { place of researches }\end{array}$} & \multicolumn{2}{|c|}{ Character of the contamination } \\
\hline & & & soil & forest floor \\
\hline $\begin{array}{c}\text { Budky, } \\
\text { Olevsk district }\end{array}$ & $\begin{array}{l}\text { Soddy medium podzolic sandy } \\
\text { loam soil on fluvioglacial sands }\end{array}$ & $\begin{array}{l}\text { coniferous forest } \\
\text { (pine) }\end{array}$ & LP & MP \\
\hline \multirow{3}{*}{$\begin{array}{l}\text { Bilokorovychi, } \\
\text { Olevsk district }\end{array}$} & \multirow{3}{*}{$\begin{array}{l}\text { Soddy medium podzolic sandy } \\
\text { soil on fluvioglacial sands }\end{array}$} & $\begin{array}{l}\text { mixed forest } \\
(\text { oak+pine })\end{array}$ & LP & LP \\
\hline & & $\begin{array}{l}\text { mixed forest } \\
\text { (birch+pine) }\end{array}$ & LP & LP \\
\hline & & $\begin{array}{l}\text { mixed forest } \\
\text { (oak+pine) }\end{array}$ & MP & MP \\
\hline
\end{tabular}

Note: $L P$ - less pollution; $M P$ - medium pollution.

Table 2

Intensity-based sequences of heavy metals accumulation in edible mushroom mycothalluses

\begin{tabular}{|l|c|}
\hline \multicolumn{1}{|c|}{ Name of the mushroom } & Sequence of accumulation \\
\hline Tubular hymenophore & $\mathrm{Zn}>\mathrm{Mn}>\mathrm{Cu}>\mathrm{Pb}>\mathrm{Cd}$ \\
\hline Xerocomus badius (Fr.) Keuhn. ex Gilb & $\mathrm{Zn}>\mathrm{Cu}>\mathrm{Mn}>\mathrm{Pb}>\mathrm{Cd}$ \\
\hline Suillus granulatus (Fr.) Kuntze & $\mathrm{Zn}>\mathrm{Mn}>\mathrm{Cu}>\mathrm{Pb}>\mathrm{Cd}$ \\
\hline Xerocomus subtomentosus (Fr.) Quel. & $\mathrm{Zn}>\mathrm{Mn}>\mathrm{Pb}=\mathrm{Cu}>\mathrm{Cd}$ \\
\hline Lamellar hymenophore & $\mathrm{Mn}>\mathrm{Zn}>\mathrm{Cu}>\mathrm{Pb}>\mathrm{Cd}$ \\
\hline Lactarius pubescens Fr. & $\mathrm{Zn}>\mathrm{Mn}>\mathrm{Cu}>\mathrm{Pb}>\mathrm{Cd}$ \\
\hline Lactarius deterrimus Groger & \\
\hline Tricholoma terreum (Fr.) Kumm & \\
\hline
\end{tabular}

It is ascertained that copper is predominantly concentrated by such macromycetes with tubular hymenophore as Suillus granulatus (Fr.) Kuntze. Zinc, as much as possible, is accumulated by Xerocomus badius (Fr.) Keuhn. ex Gilb; lead - by Suillus granulatus (Fr.) Kuntze, while cadmium - by all species under research, except for Xerocomus badius (Fr.) Keuhn. ex Gilb. Cadmium concentrators are considered to be all species of macromycetes with lamellar hymenophore under research, while lead concentrators - all species, except for Lactarius pubescens Fr.

It is found that the maximum specific quantity of samples with exceeded copper content (as compared with applicable MAC) taken from mycothalluses of macro- mycetes with tubular hymenophore falls within Xerocomus subtomentosus (Fr.) Quel. (44 $\pm 1,6 \%$ ) and Suillus granulatus (Fr.) Kuntze (38 $\pm 0,9 \%)$, while as concerns mycothalluses of Xerocomus badius (Fr.) Keuhn. ex Gilb, the exceeded MAC of copper has been revealed only in each tenth sample. The number of samples with exceeded MAC of zinc taken from mycothalluses of macromycetes with tubular hymenophore differs within the range $28 \pm 1.2 \% \ldots 74 \pm 3.1 \%$. Macromycetes with tubular hymenophore are found to be contaminated with lead and cadmium. Mycothalluses are found to have higher concentration of lead and cadmium $(67 \pm 2.8 \% \ldots 98 \pm 5.2 \%$ and $26 \pm 0.6 \% \ldots 97 \pm 4.8 \%$ of the total quantity under test accordingly) (Fig. 1). 


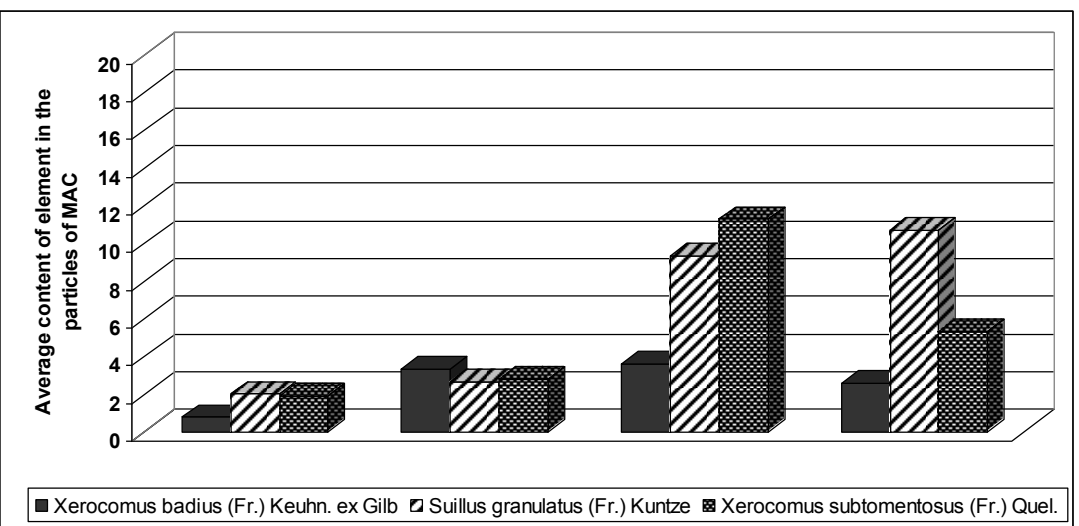

Fig. 1. Ecological safety of the macromycetes with tubular hymenophore, averaged values for 2012-2014
We have calculated the rate of not carcinogenic hazard connected with consumption of macromycetes (Table 3).

When reviewing the structure of not carcinogenic hazard origination, it should be stressed that despite of observation point, the maximum specific quantity falls within hazard connected with blood diseases $(\mathrm{HQ}=$ $=0.063)$ and hormonal disorders $(\mathrm{HQ}=$ $=0.043$ ).

The chemicals under test have included lead and cadmium selected as substances with proven carcinogenic effect (Table 4).

The maximum specific quantity of samples with exceeded copper content (as compared with applicable MAC) taken from mycothalluses of macromycetes with lamellar hymenophore falls within Lactarius deterrimus Groger, the each fourth sample of which has been found to be contaminated with the said element. The mycothalluses of Lactarius pubescens Fr. and Tricholoma terreum (Fr.) Kumm have been found to be almost uncontaminated. It is found that mycothalluses of all tested species of macromycetes with lamellar hymenophore have zinc content that is 1.4-1.7 times more than the applicable MAC. The excessive content of cadmium and lead (5.1-6.4 MAC and 1.6-13.3 MAC accordingly) has been revealed in mycothalluses of $100 \%$ of tested species of macromycetes (Fig. 2).

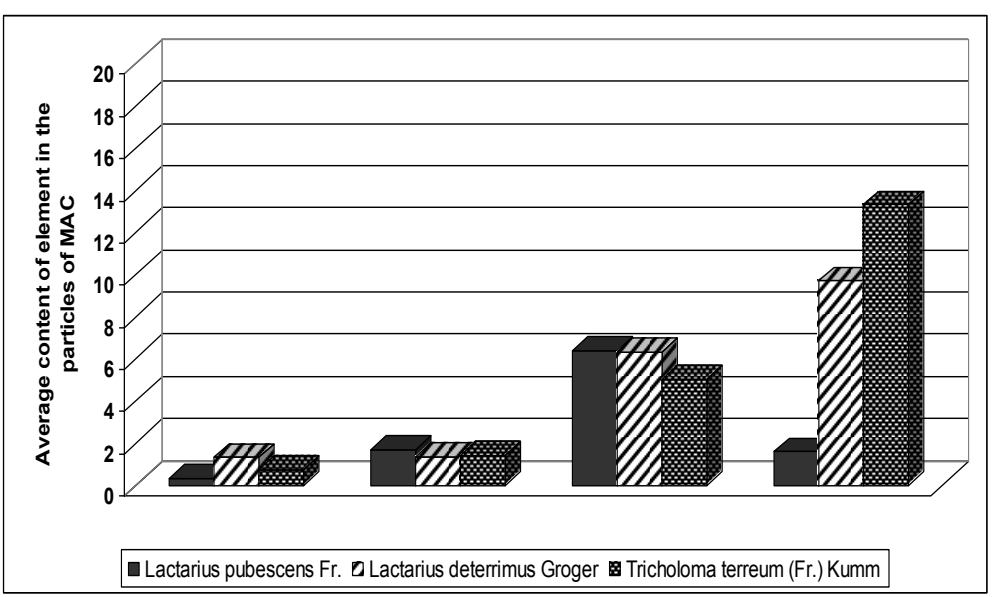

Fig. 2. Ecological safety of the macromycetes with lamellar hymenophore, averaged values for 2012-2014

Table 3

Rate of non-carcinogenic risk connected with penetration of chemicals to the organism of an inhabitants of

Olevsk of district as a result of macromycetes consumption

\begin{tabular}{|c|c|c|c|c|}
\hline $\begin{array}{l}\text { Name of } \\
\text { substance }\end{array}$ & $\begin{array}{l}\text { Average daily } \\
\text { dose (ADD), } \\
\mathrm{mg} /(\mathrm{kg} \cdot \text { day })\end{array}$ & $\begin{array}{l}\text { Reference dose for } \\
\text { chronic oral ingestion } \\
\text { RfD, mg/kg }\end{array}$ & $\begin{array}{l}\text { Hazard quotient } \\
\text { HQ }\end{array}$ & $\begin{array}{c}\text { Organs and systems of organism } \\
\text { which are struck }\end{array}$ \\
\hline Copper & $4,6 \cdot 10^{-4}$ & 0,019 & 0,024 & Gastrointestinal tract, liver \\
\hline Lead & $1,4 \cdot 10^{-4}$ & 0,0035 & 0,039 & $\begin{array}{l}\text { Central nervous system, blood, } \\
\text { developmental defects, reproduc- } \\
\text { tive system, hormonal disorders }\end{array}$ \\
\hline Cadmium & $2,8 \cdot 10^{-5}$ & 0,0005 & 0,057 & Kidneys, hormonal disorders \\
\hline Zinc & $1,7 \cdot 10^{-3}$ & 0,3 & 0,006 & Blood \\
\hline \multirow{9}{*}{$\begin{array}{l}\text { Cumulative } \\
\text { risk }\end{array}$} & \multicolumn{2}{|c|}{ HQ general } & \multicolumn{2}{|r|}{0,126} \\
\hline & \multicolumn{2}{|c|}{ HQ developmental defects } & \multicolumn{2}{|r|}{0,006} \\
\hline & \multicolumn{2}{|c|}{ HQ gastrointestinal tract } & \multicolumn{2}{|r|}{0,024} \\
\hline & \multicolumn{2}{|c|}{ HQ liver } & \multicolumn{2}{|r|}{0,024} \\
\hline & \multicolumn{2}{|c|}{ HQ blood } & \multicolumn{2}{|r|}{0,063} \\
\hline & \multicolumn{2}{|c|}{ HQ hormonal disorders } & \multicolumn{2}{|r|}{0,045} \\
\hline & \multicolumn{2}{|c|}{ HQ central nervous system } & \multicolumn{2}{|r|}{0,006} \\
\hline & \multicolumn{2}{|c|}{ HQ reproductive system } & \multicolumn{2}{|r|}{0,006} \\
\hline & \multicolumn{2}{|c|}{ HQ kidneys } & \multicolumn{2}{|r|}{0,039} \\
\hline
\end{tabular}


Table 4

Rates of individual and population risks connected with oral ingestion of chemicals to the organism of an inhabitants of Olevsk of district as a result of macromycetes consumption

\begin{tabular}{|c|c|c|c|c|c|}
\hline Carcinogen & $\begin{array}{c}\text { Individual } \\
\text { carcinogenic } \\
\text { risk ICR }\end{array}$ & $\begin{array}{c}\text { Population carcinogenic } \\
\text { risk PCR and amount of } \\
\text { the expected cases of } \\
\text { cancer }\end{array}$ & $\begin{array}{c}\text { Amount of popula- } \\
\text { tion, which lives in } \\
\text { an area of supervi- } \\
\text { sions, persons }\end{array}$ & $\begin{array}{c}\text { Level of } \\
\text { individual } \\
\text { carcinogenic } \\
\text { risk }\end{array}$ & $\begin{array}{c}\text { Annual pay- } \\
\text { ment in gen- } \\
\text { eral cancer } \\
\text { rate, persons }\end{array}$ \\
\hline Lead & $5,2 \cdot 10^{-5}$ & 5,8 & & low & 0,08 \\
\hline Cadmium & $2,1 \cdot 10^{-4}$ & 1,2 & \multirow{2}{*}{41894} & medium & 0,02 \\
\cline { 1 - 2 } $\begin{array}{c}\text { Cumulative } \\
\text { risk }\end{array}$ & $2,6 \cdot 10^{-4}$ & 6,9 & & medium & 0,10 \\
\hline
\end{tabular}

It has been found that the rate of individual carcinogenic risk connected with long life consumption of contaminated macromycetes for lead is $5.2 \cdot 10^{-5}$. Pursuant to the international criterion scale it is assessed as low (admissible) risk (the risk that as a rule requires setting specific safety hygienic regulations for population). Rate of individual carcinogenic risk for cadmium is $2.1 \cdot 10^{-4}$. Pursuant to the international criterion scale it is assessed as medium risk admissible for production conditions, however in case of residential exposure, it shall be subject to dynamic control and comprehensive examination of the sources and potential consequences of the hazardous effects required for making appropriate managerial decisions in the field of hazard management.

6. Discussion of the results of research of carcinogenic and non-carcinogenic risk from the consuming of edible mushrooms

Concentration of chemicals in fungal mycothalluses depends upon content of chemical elements in the parent rocks and mineral composition thereof; soil type, its agrochemical, physical \& chemical properties, and as well chemical composition of the forest floor. The soils located within the area under research are generally known for concentration of copper and zinc found in the top genetic horizon. The closer to parent rock, the higher concentration of cadmium, while lead is being concentrated within the top part of illuvial horizon. It shall be noted that chemical and physical properties of the soils within the area under research are considered to be rather favourable for intensified soil-to-plant or soil-to-water migration of the heavy metals. Therefore, contaminated mycological products can be found even on less-polluted soils (Table 1).

Contained in macromycetes heavy metals are distributed in uneven manner, in which connection the position and concentration of certain element are dependable either upon fungus growing locality or it species and hymenophore structure as the most fungi pollutants are accumulated in specific tissues of mycothalluses, i. e. lamellas and tubes. In general, the macromycetes with tubular hymenophore are specifically known for more intensive accumulation of copper and zinc, while the macromycetes with lamellar hymenophore - zinc and manganese (Table 2).

Ecological safety of the macromycetes under research significantly differs depending upon chemical element and fungus itself (Figures 1 and 2). It is found upon research of three species of macromycetes with tubular hymenophore that mycothalluses of Xerocomus badi- us (Fr.) Keuhn. ex Gilb have the minimum content of heavy metals, while the same of Suillus granulatus (Fr.) Kuntze are contaminated to the maximum. It is found upon research of three species of macromycetes with lamellar hymenophore that mycothalluses of Lactarius pubescens Fr. have the minimum content of heavy metals, while the same of Tricholoma terreum (Fr.) Kumm are contaminated to the maximum.

In the course of research there have been determined certain hazards connected with penetration of chemicals, inclusive of carcinogenic agents, to the organism of a man as a result of consumption of the mostly polluted macromycetes by residents of the rural settlements located within the limits of Olevsk district (Table 5). The hazard has been assessed according to the Hazard Quotient (HQ), with help of which it shall be possible to define the admissible level of penetration of chemicals to the organism of a man. Such a factor in no case has exceeded value of 1.0. All above shall be interpreted as evidence of low probability of adverse effect progress through daily penetration of the said substances to the organism of a man because of long life consumption of macromycetes. However, considering the fact that pollutants might penetrate to the organism of rural residents not only upon consumption of fungi, but also potatoes and vegetables grown by them at home grounds, the probability of not carcinogenic impacts shall be accordingly increased.

The carcinogenic risk (for the purpose of this work shall be understood as probability of increase in frequency of neoplasm development in people because of oral ingestion of hazardous chemical carcinogens) has been assessed through calculation of individual, cumulative and population risk rates (Table 6).

Total carcinogenic risk by only two identified carcinogens is $2,6 \cdot 10-4$, which is 2.6 cases of cancer rate of various localization per 10 thousand people. According to the classification levels of risk to human health, proposed by the US Agency for Environmental Protection (US EPA), carcinogenic risk from consuming contaminated with heavy metals macromycetes assessed as alarming. Note however, that due to the stochastic character of the carcinogenic process, protracted latent period, differences in age sensitivity and complicated character of temporary and age dependence the probability of death of the person is not possible to accurately predict the terms of development of malignant tumours in the population on the basis on available scientific information.

The further researches shall involve review of specific accumulation by macromycetes of $\mathrm{Co}, \mathrm{Ni}, \mathrm{Cr}$ 
and As and estimation the rate of carcinogenic and noncarcinogenic risk from the consuming of contaminated edible mushrooms.

\section{Conclusion}

It is found on the basis of the research results that:

1) zinc and cadmium (while in some cases - copper) are considered to be the principal pollutants of the mycological products grown in areas of natural woodland ecosystems within the Olevsk district of Zhytomyr Region;

2) copper and zinc are more intensively accumulated by macromycetes with tubular hymenophore, zinc and manganese - by macromycetes with lamellar one;

3 ) the rate of cumulative non-carcinogenic health risk connected with long life consumption of polluted macromycetes is 0.126 (being assessed as low), while the rate of cumulative carcinogenic risk is $2.6 \cdot 10^{-4}$ (being assessed as medium).

\section{References}

1. Bilyavskyj, Yu. A. Quality monitoring of edible macromycetes growing in an ecological conditions of Zhytomyr Polissia region [Text] / Yu. A. Bilyavskyj, T. M. Myslyva // Visnyk ZhNAEU. - 2014. - Vol. 1, Issue 2. - P. 3-12.

2. Collin-Hansen, C. Mushrooms from two metal-contaminated areas in Norway: occurrence of metals and metallothionein-like proteins [Text] / C. Collin-Hansen, K. E. Yttri, R. A. Andersen, B. O. Berthelsen, E. Steinnes // Geochemistry: Exploration, Environment, Analysis. - 2002. - Vol. 2, Issue 2. - P. 121-130. doi: 10.1144/1467-787302-015

3. Pérez, A. A. Levels of essential and toxic elements in Porphyra columbina and Ulva sp. from San Jorge Gulf, Patagonia Argentina [Text] / A. A. Pérez, S. S. Farías, A. M. Strobl, L. B. Pérez, C. M. López, A. Piñeiro et. al. // Science of The Total Environment. - 2007. - Vol. 376, Issue 1-3. - P. 51-59. doi: $10.1016 /$ j.scitotenv.2006.11.013

4. Campos, J. A. Substrate role in the accumulation of heavy metals in sporocarps of wild fungi [Text] / J. A. Campos, N. A. Tejera, C. J. Sánchez // BioMetals. - 2009. - Vol. 22, Issue 5. - P. 835-841. doi: 10.1007/s10534-009-9230-7

5. Elekes, C. C. The bioaccumulation of some heavy metals in the fruiting body of wild growing mushrooms [Electronic resource] / C. C. Elekes, G. Busuioc, G. Ionita // Notulae Botanicae Horti Agrobotanici Cluj-Napoca. - 2010. - Vol. 38, Issue 2. - P. 147-151. - Available at: http://www. notulaebotanicae.ro/index.php/nbha/article/viewFile/4736/4526

6. Ita, B. N. Heavy metal levels in fruiting bodies of edible and non-edible mushrooms from the Niger Delta Region of Nigeria [Electronic resource] / B. N. Ita, J. P. Essien, G. A. Ebong // Journal of Agriculture \& Social Sciences. - 2006. Vol. 2, Issue 2. - P. 84-87. - Available at: http://www. researchgate.net/publication/242074037_Heavy_Metal_Levels_in_ Fruiting_Bodies_of_Edible_and_Non-edible_Mushrooms_from_ the_Niger_Delta_Region_of_Nigeria

7. Muhsin, K. Minor element and heavy metal contents of wild growing and edible mushrooms from western black sea region of Turkey [Text] / K. Mushin, A. Afyon, D. Yağız // Fresenius Environmental Bulletin. - 2007. - Vol. 16, Issue 11a. P. 1359-1362. - Available at: http://www.psp-parlar.de/pdf/F_ 27_012_Original_Paper_pp1359_1362.pdf

8. Nekos, A. N. Osoblyvosti nakopychennya vazhkyh metaliv u systemi «gryb - lisova pidstylka - grunt» (na prykladi Dubrovytskogo rajonu Rivnenskoi oblasti) [Text] / A. N. Nekos, O. O. Rukavychka // Ludyna ta dovkillya. Problemy neoekologii. - 2008. - Vol. 1-2. - P. 54-61.

9. Gololobova, O. O. Formuvannua ekologichnoi jakosti istivnyh grybiv v pryrodnyh landshaftah Zakarpattya [Text] /
O. O. Gololobova , L. V. Tymko // Ludyna ta dovkillya. Problemy neoekologii. - 2011. - Vol. 1-2. - P. 140-148.

10. Orlov, O. O. Akumulacija ${ }^{137} \mathrm{Cs}$ plodovymy tilamu makromitsetiv riznyh trofichnyh grup na sfagnovyh bolotah Ukrainskogo Polissya [Text] / O. O. Orlov // Lisnytstvo i agrolisomelioratsia. - 2003. - Vol. 104. - P. 13-23.

11. Orlov, O. O. Vplyv trofichnoi ta topichnoi grup openka spravzhnogo (Armillariella mellea (Fr.) Karst.) na intensyvnist akumulacii ${ }^{137} \mathrm{Cs}$ u plodovyh tilah [Text] / O. O. Orlov, S. P. Irklienko, V. M. Turko, T. V. Kurbet // Visnyk DAEU. - 1999. - Vol. 1-2. - P. 11-22.

12. Vinichuk, M. Selected metals in various fractions of soil and fungi in a Swedish forest [Text] / M. Vinichuk // ISRN Ecology. - 2012. - Vol. 2012. - P. 1-7. doi: 10.5402/2012/ 521582

13. Onishchenko, G. G. Osnovy otsenki riska dlya zdorovja naseleniya pri vozdejstvii himicheskih veshchestv, zagryaznyaushchih okruzhayushchuyu sredu [Text] / G. G. Onishchenko, S. M. Novikov, Yu. A. Rahmanin et. al; Yu. A. Rahmanina, G. G. Onishchenka (Eds.). - Moscow, 2002. -408 p.

\section{References}

1. Bilyavskyj, Yu. A., Myslyva, T. M. (2014). Quality monitoring of edible macromycetes growing in an ecological conditions of Zhytomyr Polissia region. Visnyk ZhNAEU, 1 (2), 3-12.

2. Collin-Hansen, C., Yttri, K. E., Andersen, R. A., Berthelsen, B. O., Steinnes, E. (2002). Mushrooms from two metal-contaminated areas in Norway: occurrence of metals and metallothionein-like proteins. Geochemistry: Exploration, Environment, Analysis, 2 (2), 121-130. doi: 10.1144/1467-787302015

3. Pérez, A. A., Farías, S. S., Strobl, A. M., Pérez, L. B., López, C. M., Piñeiro, A. et. al. (2007). Levels of essential and toxic elements in Porphyra columbina and Ulva sp. from San Jorge Gulf, Patagonia Argentina. Science of The Total Environment, 376 (1-3), 51-59. doi: 10.1016/j.scitotenv 2006.11.013

4. Campos, J. A., Tejera, N. A., Sánchez, C. J. (2009). Substrate role in the accumulation of heavy metals in sporocarps of wild fungi. BioMetals, 22 (5), 835-841. doi: 10.1007/s10534-009-9230-7

5. Elekes, C. C., Busuioc, G., Ionita, G. (2010). The bioaccumulation of some heavy metals in the fruiting body of wild growing. Notulae Botanicae Horti Agrobotanici ClujNapoca, 38 (2), 147-151. Available at: http://www. notulaebotanicae.ro/index.php/nbha/article/viewFile/4736/4526

6. Ita, B. N., Essien, J. P., Ebong, G. A. (2006). Heavy metal levels in fruiting bodies of edible and non-edible mushrooms from the Niger Delta Region of Nigeria. Journal of Agriculture \& Social Sciences, 2 (2), 84-87. Available at: http://www.researchgate.net/publication/242074037_Heavy_M etal_Levels_in_Fruiting_Bodies_of_Edible_and_Non-

edible_Mushrooms_from_the_Niger_Delta_Region_of_Nigeria

7. Muhsin, K., Afyon, A., Yağız, D. (2007). Minor element and heavy metal contents of wild growing and edible mushrooms from western black sea region of Turkey. Fresenius Environmental Bulletin, 16 (11a), 1359-1362. Available at: http://www.psp-

parlar.de/pdf/F_27_012_Original_Paper_pp1359_1362.pdf

8. Nekos, A. N., Rukavychka, O. O. (2008). Osoblyvosti nakopychennya vazhkyh metaliv u systemi «gryb - lisova pidstylka - grunt» (na prykladi Dubrovytskogo rajonu Rivnenskoi oblasti). Ludyna ta dovkillya. Problemy neoekologii, $1-2,54-61$.

9. Gololobova, O. O., Tymko, L. V. (2011). Formuvannua ekologichnoi jakosti istivnyh grybiv $\mathrm{v}$ pryrodnyh landshaftah Zakarpattya. Ludyna ta dovkillya. Problemy neoekologii, 1-2, 140-148. 
10. Orlov, O. O. (2003). Akumulacija ${ }^{137} \mathrm{Cs}$ plodovymy tilamu makromitsetiv riznyh trofichnyh grup na sfagnovyh bolotah Ukrainskogo Polissya. Lisnytstvo i agrolisomelioratsia, 104, 13-23.

11. Orlov, O. O., Irklienko, S. P., Turko, V. M., Kurbet, T. V. (1999). Vplyv trofichnoi ta topichnoi grup openka spravzhnogo (Armillariella mellea (Fr.) Karst.) na intensyvnist akumulacii ${ }^{137} \mathrm{Cs}$ u plodovyh tilah. Visnyk DAEU, 1-2, 11-22.
12. Vinichuk, M. (2012). Selected Metals in Various Fractions of Soil and Fungi in a Swedish Forest. ISRN Ecology, 2012, 1-7. doi: 10.5402/2012/521582

13. Onishchenko, G. G., Novikov, S. M., Rahmanin, Yu. A. et. al; Rahmanina, Yu. A., Onishchenka, G. G. (Eds.) (2002). Osnovy otsenki riska dlya zdorovja naseleniya pri vozdejstvii himicheskih veshchestv, zagryaznyaushchih okruzhayushchuyu sredu. Moscow, 408.

Дата надходження рукопису 16.09.2015

Myslyva Tamara, Associate professor, Candidate of agricultural science, The department of environmental protection and rational nature management, Zhytomyr National Agroecological University, Stariy blvd., 7, Zhytomyr, Ukraine, 10008

Bilyavskyj Yurij, Associate professor, Candidate of agricultural science, The department of environmental protection and rational nature management, Zhytomyr National Agroecological University, Stariy blvd., 7, Zhytomyr, Ukraine, 10008

Nadtochij Petro, Professor, Doctor of agricultural science, head of the department, The department of environmental protection and rational nature management, Zhytomyr National Agroecological University, Stariy blvd., 7, Zhytomyr, Ukraine, 10008

\author{
УДК 581.524.1 \\ DOI: 10.15587/2313-8416.2015.51715
}

\title{
НЕКОТОРЫЕ ТЕОРЕТИЧЕСКИЕ И МЕТОДИЧЕСКИЕ АСПЕКТЫ ПРОГНОЗИРОВАНИЯ СОСТОЯНИЯ ЛЕСНЫХ ФИТОЦЕНОЗОВ
}

\author{
(C) В. Г. Скляр
}

Предложен подход к прогнозированию состояния лесных фитоценозов, базирующийся на оченке количества на площадях возобновления особей мелкого подроста класса «а» виталитета. Показано, что на севере северо-восточной Украины в будущем ожидается расширение площадей сосново-дубовых и дубовых лесов, в центральной - возрастание удельного веса ясеневых и кленово-ясеневых сообществ, в южной - увеличение в составе древостоев Acer platanoides

Ключевые слова: естественное возобновление, лесные фитоценозы, мелкий подрост, популяция, виталитет, ииротный макроградиент

An approach to forecasting the state of the forest phytocoenosis, based on an assessment of the number of individuals in the areas of natural regrowth of small undergrowth vitality class "a». It is shown that in the north of the north-east of Ukraine in the future is expected to expand the areas of oak and pine-oak forests, in the central - the increase in the proportion of ash tree and maple-ash tree phytocoenosis, in the south-increase of Aser platanoides in the structure of forests

Keywords: natural regrowth, forest phytocoenosis, small undergrowth, population, vitality, latitudinal macrogradient

\section{1. Введение}

Лесовозобновление является механизмом, лежащим в основе обеспечения функционирования лесных фитоценозов [1]. Кроме того, по его протеканию можно судить о прошлом, настоящем и, что особенно важно с теоретической и практической точек зрения, - будущем лесных фитоценозов того или иного региона.

\section{2. Анализ литературных данных и поста-} новка проблемы

Традиционно в лесоводческой науке при составлении прогнозов первостепенное внимание уделяют общему количеству подроста, произрастающе- му на площадях возобновления. Считается, что будущее лесных экосистем в наибольшей степени определяется величиной этого показателя [2-7]. Качество подроста практически игнорируется. Отнесение подроста к категории благонадежный, сомнительный, неблагонадежный или здоровый, нежизнеспособный, поврежденный недостаточно информативно [8]. Да и ориентировано оно преимущественно на крупный подрост, высотой 1-1,5 м.

На основании анализа собранных полевых материалов и многочисленных литературных источников нами был сделан вывод о том, что такой подход не позволяет учесть всех тонкостей процесса самовозобновления лесов и составить достаточно точный про- 